\title{
TEMPORAL ASPECT OF THE TERRESTRIAL INVERTEBRATE RESPONSE TO MOISTURE DYNAMIC IN TECHNOSOLS FORMED AFTER RECLAMATION AT A POST-MINING SITE IN UKRAINIAN STEPPE DRYLANDS
}

\author{
OLEXANDER ZHUKOV $\otimes^{1}$, OLGA KUNAH ${ }^{2}$, MARINA FEDUSHKO ${ }^{1}$, ANNA BABCHENKO ${ }^{3}$, AVA UMEROVA ${ }^{1}$
}

${ }^{1}$ Bogdan Khmelnitsky Melitopol State Pedagogical University, Hetmanska st., 20, 72318, Melitopol, Ukraine; e-mail: zhukov_dnipro@ukr.net

${ }^{2}$ Oles Gonchar Dnipro National University, Gagarin av., 72, 49000, Dnipro, Ukraine; e-mail: kunah_olga@ukr.net

${ }^{3}$ Ukrainian State University of Chemical Technology, Gagarin av., 8, 49005, Dnipro, Ukraine; e-mail: lineanna83@gmail.com

$\triangle$ Corresponding author

Received: 19 September 2019 / Accepted: 13.February 2020

Abstract

Zhukov O., Kunah O., Fedushko M., Babchenko A., Umerova A.: Response to moisture dynamic in technosols formed after reclamation at a postmining site in Ukrainian steppe drylands. Ekológia (Bratislava), Vol. 40, No. 2, p. 178-188, 2021.

\begin{abstract}
Different approaches were applied to assess soil moisture optima and tolerance of the ecological niche temporal projection of terrestrial invertebrates within an experimental polygon created to investigate the reclamation processes after deep underground hard-rock mining in the Ukrainian steppe drylands. Sampling was carried out in 2013-2015 on a variant of artificial soil (technosols). To investigate the spatiotemporal variation in the abundance, species richness and species composition of invertebrate assemblages the animals were sampled using pitfall traps. The readily available water for plants, precipitation, wind speed, atmospheric temperature, atmospheric humidity, and atmospheric pressure were used as environmental predictors. The two-dimension geographic coordinates of the sampling locations were used to generate a set of orthogonal eigenvector-based spatial variables. Time series of sampling dates were used to generate a set of orthogonal eigenvector-based temporal variables. Weighted averaging, generalized linear mixed models, Huisman-Olff-Fresco models expanded by Jansen-Oksanen, correspondence analysis, and constrained correspondence analysis were used to estimate soil moisture species optima and tolerance. The moisture content in the technosols was revealed to be the most important factor determining the temporal dynamics of terrestrial invertebrate community in conditions of semi-arid climate and the ecosystem which formed as a result of the reclamation process. The species response to the soil water content is affected not only by the soil water content but also by the complex of the other environmental, temporal, and spatial factors. The effect of other factors on the species response must be extracted previously to find real estimations of the species optima and tolerance.
\end{abstract}

Key words: species response, niche, optima, tolerance, reclamation, gradient, temporal dynamic.

\section{Introduction}

The temporal and spatial dynamic of population abundance or community diversity may be explained on the basis of the niche theory (Schoener, 1974; Tokeshi, 1999). A set of biotic and abiotic conditions under which a given organism can survive and reproduce is considered as its ecological niche (Hutchinson, 1957). Environmental filtering, biotic interactions, and interspecific competition have important implications for patterns of species diversity and composition (Chase, Myers, 2011). The measurement of niche properties concerns such questions as the problem of range, the problem of spacing, and the problem of nonlinearity (Colwell, Futuyma, 1971). The niche may be quantitatively described by niche position and niche width (Gregory, Gaston, 2000). The species response parameters like optima or niche width depend on the model shape (Jansen, Oksanen, 2013) and can be used to explain the ecological behavior of species (Michaelis, Diekmann, 2017). All model attributes, apart from the optimum, are heavily influenced by the properties of the data set, which is why it appears to be difficult to establish the "true" niche characteristics of a species (Michaelis, Diekmann, 2017). Niche width is the distance through a niche along some particular line in niche space (Colwell, Futuyma, 1971). Niche width is essentially the inverse of ecological specialization (Kohn, 1968). The different aspects of the niche size such as climatic tolerance, habitat, or diet breadth were revealed to affect the species range size (Gaston et al., 1997). The term specialization is used for different levels of the biological organization (individual, species, population, or community) and measured at very different spatial scales (Devictor et al., 2010). The intraspecific and interspecific interactions and environmental conditions affect niche position and niche width (Brown, 1999; Lawton, 1999). Interspecific competition is a dominant force in animal communities which induces niche shifts (Tarjuelo et al., 2017). The general diversity theory integrating metabolic principles with niche-based community assembly predicts that decrease in temperature should 
reduce niche widths along environmental gradients due to decreasing growth rates, and the changing niche widths should lead to contrasting $\alpha$ - and $\beta$-diversity patterns (Okie et al., 2015).

For the unimodal species response model, the simplest way to estimate the species optimum is by calculating the weighted average of the value of environmental variables in the samples where the species is present (Šmilauer, Lepš, 2014). The weighted averaging approach for species relative importance assessment was developed by Curtis and McIntosh (1951). The Gaussian bell-shaped response model is the classical and frequently used model (Gauch, Whittaker, 1972). If the relationships between species occurrences and values of a quantitative environmental variable conform to bell-shaped curves, the optimal for species values of the environmental variable may be found by averaging over the samples in which a species occurs or can be weighted by species abundance (ter Braak, Looman, 1986). Correspondence analysis is based on the assumption of symmetrical unimodal species responses along environmental gradients (ter Braak, 1985), which is why weighted averaging is the basis of this ordination technique (Hill, 1973). The generalized linear models allow the modeling of symmetric bell-shaped response curves (ter Braak, Looman, 1986). The Huisman-Olff-Fresco (HOF) approach provides a wide set of the models which are characterized by a statistical correctness, flexibility, and ecological interpretability (Huisman et al., 1993). This model framework was expanded to comprise seven ecological niche patterns (Jansen, Oksanen, 2013).

The principle of the ecological niche has to be used for conceptualization of the restoration of the mine-degraded lands (Zhenqi et al., 2012; Kunakh et al., 2018). Deep underground hard-rock mining has a considerable impact on the landscape, transforming original habitats and leaving landscapes in altered states (Hodecek et al., 2015; Klimkina et al., 2018; Zhukov, Maslikova, 2018; Yorkina et al., 2019). The landscape transformation due to open-pit coal mining causes major changes in terrain structures, waterways, microclimates, land uses, and living organism communities (Sklenicka et al., 2004; Hendrychova et al., 2011; Yorkina et al., 2018; Zadorozhnaya et al., 2018). The technical and biological reclamation phase is essential for managing a disturbed landscape (Hildmann, Wunsche, 1996; Rehor et al., 2006; Hodecek et al., 2016). The technical phase of the reclamation processes is a significant disturbance that slows down the successional rate of beetle communities (Hodecek et al., 2016). The soil formation is essential for successful reclamation of post-mining sites (Madej, Kozub, 2014). The soil macrofauna distribution pattern was found to be strongly related to soil development after reclamation (Ge et al., 2014; Zhukov et al., 2018). Animal post-reclamation succession can be influenced by plant community diversity or by abiotic conditions (Hendrychova, 2008; Buchori et al., 2018; Zhukov, Gadorozhnaya, 2016). The "niche-breadth" hypothesis sensu Brown (1984) was applied to explain the of local communities' structure in non-reclaimed mining sites (Brandle et al., 2003). Investigations of niche characteristics of the terrestrial arthropods are still rare (Entling et al., 2007), and there is no evidence about species response within terrestrial invertebrates groups to the effect of the environmental gradients of the reclaimed lands.

Drylands include arid, semi-arid, and dry subhumid areas. Water is the main limiting factor affecting dynamic of the ecological processes in many semi-arid grassland ecosystems (Chase et al., 2000). Within dryland areas, precipitation is in deficit, exhibits a high temporal variability, and is mostly unpredictable
(Reynolds et al., 2007). Water, soil nutrients, and plant biomass are the important resources in arid or semi-arid conditions, for which long periods of low abundance are interrupted by relatively short periods of high abundance. Short periods of high resource availability are usually triggered by rainfall events until moisture is depleted (Schwinning, Sala, 2004). Ecological processes in arid lands are often described by the pulse-reserve paradigm (Collins et al., 2014). High air temperatures, low humidity, and abundant solar radiation result in high potential evapotranspiration, which may lead to water deficit. Many dryland soils contain small amounts of organic matter and have low aggregate strength (Reynolds et al., 2007). These ecological conditions are the most extreme within anthropogenically transformed territories, including reclamation ecosystems (Hendrychova, 2008).

In this study, we applied different approaches to assess soil moisture optima and tolerance of the ecological niche temporal projection of the terrestrial invertebrates within an experimental polygon created to investigate the dynamic of reclamation processes after deep underground hard-rock mining in the Ukrainian steppe drylands. Our main objective here was to determine whether the variability of water content in the technosols affects the temporal dynamic of the terrestrial invertebrates and to find properties of the species response curves to soil water content. We formulated three hypotheses. Hypothesis 1: Species response to the soil water content depended not only directly on soil water content but was also affected by the complex of other environmental, temporal, and spatial factors. To find real estimates of the species optima and tolerance, the effect of other factors on the species response must be extracted previously. Hypothesis 2: Each ecological group of the terrestrial invertebrates homogenous with respect to the humidity gradient (xerophilous, xeromesophilous, mesophilous) has a specific set of models best explaining a species response to water content in technosols. $\mathrm{Hy}$ pothesis 3: The asymmetric species response to soil moisture in different parts of the soil humidity range is predominantly due to different causes. The abiotic factors are the most important in the arid margin of the gradient, and the biotic factors are prevalent in the most humid margin of the gradient.

\section{Material and methods}

\section{Experimental polygon}

The research was carried out at the Research Centre of the Dnipro State Agrarian and Economic University in Pokrov city. The experimental polygon for the study of optimal regimes of agricultural recultivation was established in 1968-1970. Sampling was carried out on a variant of artificial soil (technosols) formed on loess-like loam, red-brown clay, green-gray clay, technological mixture of the rocks, and loess-like loam with a humus-rich 70 $\mathrm{cm}$ top soil layer (the geographic coordinates of the experimental polygon are $47^{\circ} 38^{\prime} 55.24^{\prime \prime}$ N.L., $34^{\circ} 08^{\prime} 33.30^{\prime \prime}$ E.L.) (Yorkina et al., 2018). The data set comprised 20 plots from five technosol types presented within the experimental polygon (Fig. 1).

\section{Animal data collection}

To investigate the temporal dynamic in the abundance, species richness, and species composition of invertebrate communities 


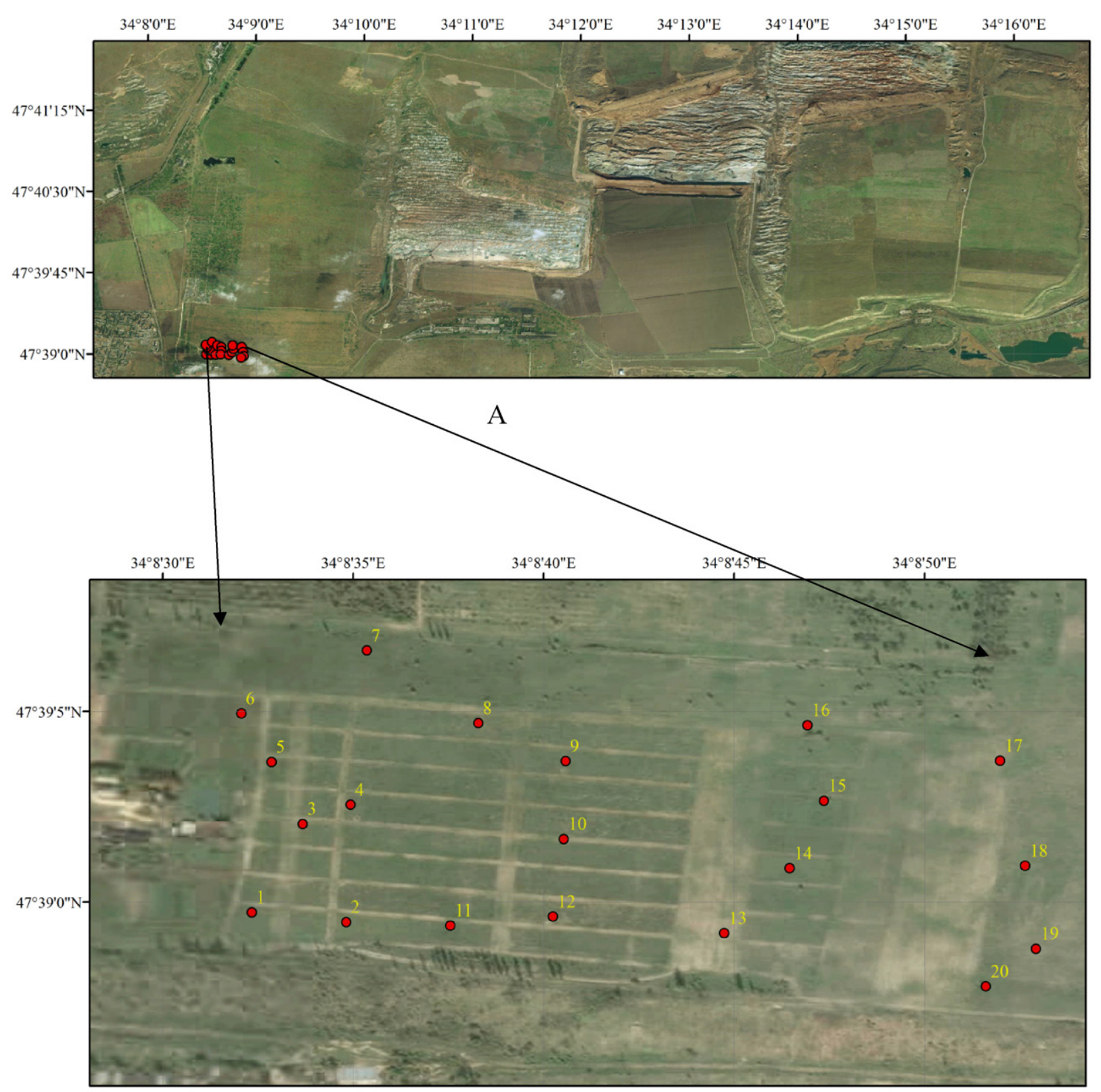

B

Fig. 1. The satellite image (https://www.bing.com) of the landscape transformed after open-pit hard-rock mining (A) and Research Centre of the Dnipro State Agrarian and Economic University in Pokrov (Ukraine) (B). Plots: 1, 2, 3, 5, 6 - technosols on loess-like loam, 6, 7, 8, 9, 10 - technosols on red-brown clay, 11, 12 - technosols on green-gray clay, 13, 14, 15, 16 - technosols formed on loess-like loam with humusrich $70 \mathrm{~cm}$ top soil layer, and 17, 18, 19, 20 - technosols on technological mixture of rocks.

within the experimental polygon, animals were sampled using pitfall traps (Knapp et al., 2019). In each plot, three pitfalls were placed in a triangle of $3 \mathrm{~m}$ base (Desender et al., 1999; Pontegnie et al., 2005) and emptied each 7-9 days. In 2013, pitfalls were placed on April 9, in 2014 - on April 5, and in 2015 - on April 6 . The pitfall traps were made of 1-litre glass cups $(10 \mathrm{~cm}$ in diameter) buried in the soil with the rim of the cup with the soil surface. The cups were filled with $250 \mathrm{ml}$ of preservative fluid made from concentrated $\mathrm{NaCl}$ solution, which seems to be efficient for collecting invertebrates and is relatively non-toxic to non-target organisms.

\section{Environmental predictors}

The readily available water for plants $(R A W, \mathrm{~mm}$ in $1 \mathrm{~m}$ soil layer), precipitation $(\mathrm{mm})$, wind speed $(\mathrm{m} / \mathrm{s})$, atmospheric temper- 
ature (daily minimum, daily maximum, daily mean, ${ }^{\circ} \mathrm{C}$ ), atmospheric humidity (\%), and atmospheric pressure ( $\mathrm{gPa}$ ) were used as environmental predictors (Kunah et al., 2019). The Nikopol Meteorological Station data were used.

\section{Spatial and temporal predictors}

The two-dimension geographic coordinates of sampling locations were used to generate a set of orthogonal eigenvector-based spatial variables (spatial dbMEMs), each of them representing a pattern of particular scale within the extent of the sampling area (Dray et al., 2006). Likewise, but only the one-dimension time series of sampling dates were used to generate a set of orthogonal eigenvector-based temporal variables (time dbMEMs), each of them representing a pattern of particular scale within the extent of the investigated time period (Borcard, Legendre, 2002; Angeler et al., 2011).

\section{Ordination approaches and methods for niche param- eters estimation}

Weighted averaging was used to estimate the species optimal value along the ecological gradient (ter Braak, Looman, 1986). The species tolerance was calculated as the square root of the weighted mean of the squared differences between the species optimum and the actual value in the sample (Šmilauer, Lepš, 2014). Generalized linear mixed models were used for modeling species-environment relationships (Jamil, ter Braak, 2013). Huisman-Olff-Fresco models (Jansen, Oksanen, 2013; Michaelis, Diekmann, 2017) were fitted in the R statistical program (v. 3.3.1) (R Core Team, 2019) using the package "eHOF" (Jansen, Oksanen, 2013, version 3.2.2). We subjected the Hellingertransformed abundance matrix of species to correspondence analysis (CA), constrained correspondence analysis (CCA), and constrained redundancy analysis (RDA) to extract the major patterns of variation (Legendre, Birks, 2012; ter Braak, Smilauer, $2015)$. For the statistical analyses, we used the appropriate procedures of Statistica (Version 5.5, StatSoft Inc., http://www.statsoft. com) or R (version 3.5.2; R Core Team, 2019).

\section{Results}

In total, 257,437 invertebrate (Arthropoda and Mollusca) individuals of 6 classes, 13 orders, 50 families, and 202 species or parataxonomic units were recorded (Table 1). Diplopoda was most abundant taxonomic group, though it was represented only one species Rossiulus kessleri (Lohmander, 1927). This species took up $49.4 \%$ of the total community abundance. Coleoptera and Araneae were the considerably numerous taxonomic groups, which took up $22.4 \%$ and $18.2 \%$ of the total community abundance. These taxa were the most species rich. Coleoptera was represented by 122 species, and Araneae was represented by 67 species. Seventy-one species among the investigated 202 species occurred 50 times or less.

HOFJO approach provides opportunities for species response modeling using more alternative models. The model IV often is the most optimal model of the species response to soil moisture gradient. Somewhat less often, the optimal models are III, V, and VII (Fig. 2). Thus, species response to the influence

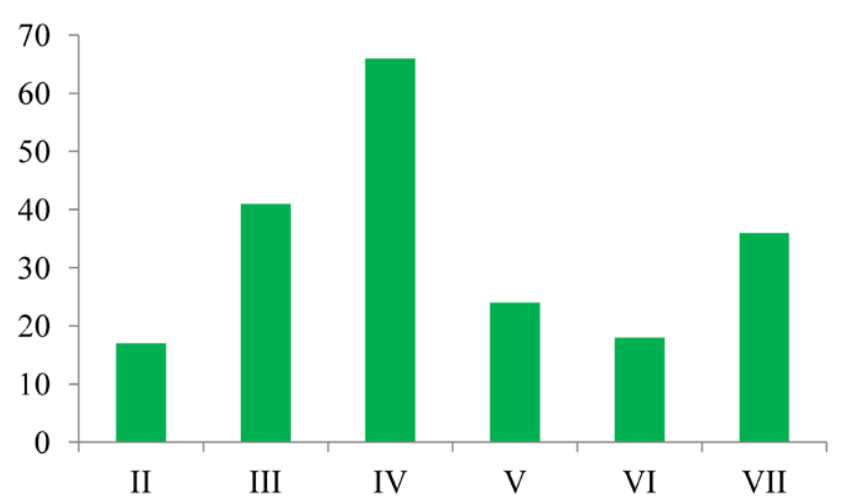

Fig. 2. The optimal models distribution of species response to the soil moisture gradient. $X$-axis - HOF and two additional models of the species responses to the soil moisture gradient; $Y$-axis - the number of species for which model is the best according to $\mathrm{AIC}_{c}$.

of the moisture content in the soil can be described by Gaussian curve (model IV), or close to it asymmetric bell-shaped curve (model V). For ordination procedure of the community with monotonic patterns, the more appropriate is RDA, and with unimodal patterns, the more appropriate procedure is CCA (ter Braak, Prentice, 1988). DCA revealed that the length of the first axis gradient is more than 2 standard deviations (2.49 in our case), which points to the appropriateness of applying the correspondence analysis (CA) and the constrained correspondence analysis (CCA) as an ordination procedure.

CA-ordination axes may be explained by the environmental factors, time and spatial variables, and the technosol type (Table 2). The first four CA axes are able to explain $19.1 \%$ of the total community variation. The axis 1 is the most correlated with soil moisture (RAW), but the significant correlation is found for soil moisture and CA axis 4 . Temperature and atmospheric pressure are considerable predictors of the invertebrate community variation. The significance of the time predictors is strongly ranged in descending order of the temporal dbMEMs variables. This result reveals that the importance of the time oscillations decreases with increasing of their frequencies. The spatial predictors considerably affect the community variation.

The HOFJO approach showed that species responses to soil moisture gradient are mainly bell shaped (for which CCA is the best ordination procedure). But the responses of many species are monotonic (for which the RDA is the best ordination procedure). The fractioning of the animal community variability in relation to meteorological data, spatial and time predictors, and the technosol type was performed on the basis of both CCA and RDA (Fig. 3). The variation partitioning of the community based on CCA approach points to the major role of the complex factors that are the result of the interaction of temporal and spatial factors, as well as the temporal, spatial, and meteorological factors. The results based on RDA approach also indicate the significant role of interaction between weather and time factors. These results point to the need for extraction of the role of soil moisture factor interactions with other factors to assess precisely the influence of soil moisture on the dynamics of invertebrate communities. 
Table 1. Pitfall trapped invertebrates with number of individuals and species (parataxonomic units).

\begin{tabular}{|c|c|c|c|c|c|c|c|}
\hline \multirow{2}{*}{ Taxa } & \multirow{2}{*}{ Family } & \multicolumn{3}{|c|}{ Number of individuals } & \multicolumn{3}{|c|}{ Number of species } \\
\hline & & 2013 & 2014 & 2015 & 2013 & 2014 & 2015 \\
\hline \multicolumn{8}{|l|}{ Arthropoda } \\
\hline \multicolumn{8}{|l|}{ Crustacea } \\
\hline Isopoda & Trachelipodidae & 850 & 255 & 1853 & 1 & 1 & 1 \\
\hline \multicolumn{8}{|l|}{ Diplopoda } \\
\hline Julida & Julidae & 45,649 & 34,170 & 47,453 & 1 & 1 & 1 \\
\hline \multicolumn{8}{|l|}{ Chilopoda } \\
\hline Geophilomorpha & Geophilidae & 15 & 5 & 2 & 1 & 1 & 1 \\
\hline Lithobiomorpha & Lithobiidae & 72 & 31 & 284 & 1 & 1 & 1 \\
\hline Scolopendromorpha & Cryptopidae & 105 & 22 & 237 & 1 & 1 & 1 \\
\hline Scutigeromorpha & Scutigeridae & 7 & 11 & 2 & 1 & 1 & 1 \\
\hline \multicolumn{8}{|l|}{ Arachnida } \\
\hline \multirow{15}{*}{ Araneae } & Agelenidae & 351 & 46 & 628 & 4 & 4 & 4 \\
\hline & Dictynidae & 20 & - & 15 & 1 & - & 1 \\
\hline & Gnaphosidae & 8399 & 4195 & 9223 & 20 & 17 & 18 \\
\hline & Linyphiidae & 36 & 3 & 19 & 2 & 1 & 2 \\
\hline & Liocranidae & 18 & 2 & 11 & 3 & 1 & 2 \\
\hline & Lycosidae & 3343 & 1536 & 4789 & 8 & 7 & 8 \\
\hline & Miturgidae & 114 & 2 & 255 & 2 & 1 & 2 \\
\hline & Oxyopidae & 23 & 11 & 15 & 2 & 1 & 2 \\
\hline & Philodromidae & 873 & 521 & 630 & 6 & 2 & 5 \\
\hline & Pisauridae & 35 & 11 & 12 & 2 & 1 & 2 \\
\hline & Salticidae & 434 & 96 & 652 & 5 & 5 & 5 \\
\hline & Theridiidae & 108 & 17 & 95 & 3 & 1 & 3 \\
\hline & Thomisidae & 952 & 524 & 992 & 7 & 4 & 7 \\
\hline & Titanoecidae & 80 & 58 & 5 & 1 & 1 & 1 \\
\hline & Dysderidae & 33 & 11 & 17 & 1 & 1 & 1 \\
\hline Opiliones & Phalangiidae & 11 & - & 11 & 1 & - & 1 \\
\hline \multicolumn{8}{|l|}{ Insecta } \\
\hline \multirow{23}{*}{ Coleoptera } & Aphodiidae & 17 & 27 & 34 & 1 & 1 & 1 \\
\hline & Buprestidae & 29 & - & 22 & 1 & - & 1 \\
\hline & Byrrhidae & 52 & - & 35 & 1 & - & 1 \\
\hline & Cantharididae & 12 & 2 & 9 & 1 & 1 & 1 \\
\hline & Carabidae & 5870 & 5825 & 4866 & 47 & 39 & 46 \\
\hline & Cerambycidae & 196 & 55 & 57 & 5 & 2 & 4 \\
\hline & Cetoniidae & 75 & 43 & 14 & 3 & 3 & 2 \\
\hline & Chrysomelidae & 73 & 69 & 75 & 1 & 1 & 1 \\
\hline & Coccinellidae & 78 & 20 & 81 & 2 & 2 & 1 \\
\hline & Curculionidae & 319 & 257 & 483 & 9 & 7 & 7 \\
\hline & Dermestidae & 3314 & 2421 & 3047 & 2 & 2 & 2 \\
\hline & Dynastidae & 190 & 94 & 284 & 1 & 1 & 1 \\
\hline & Elateridae & 245 & 212 & 287 & 3 & 2 & 3 \\
\hline & Geotrupidae & 101 & 5 & 54 & 1 & 1 & 1 \\
\hline & Histeridae & 1510 & 1330 & 1598 & 6 & 5 & 6 \\
\hline & Lucanidae & 20 & 44 & - & 1 & 1 & - \\
\hline & Meloidae & 518 & 505 & 172 & 4 & 3 & 4 \\
\hline & Scarabaeidae & 682 & 395 & 624 & 7 & 5 & 7 \\
\hline & Silphidae & 750 & 555 & 1371 & 6 & 5 & 6 \\
\hline & Staphilinidae & 507 & 165 & 695 & 4 & 2 & 4 \\
\hline & Tenebrionidae & 9000 & 4489 & 7455 & 12 & 11 & 12 \\
\hline & Trogidae & 109 & 81 & 107 & 3 & 2 & 3 \\
\hline & Melolonthidae & 8 & 25 & - & 1 & 1 & - \\
\hline Hemiptera & Pyrrhocoridae & 1473 & 1358 & 1467 & 1 & 1 & 1 \\
\hline Lepidoptera & Noctuidae & 633 & 848 & 732 & 1 & 1 & 1 \\
\hline Orthoptera & Acrididae & 5778 & 7764 & 4324 & 1 & 1 & 1 \\
\hline \multicolumn{8}{|l|}{ Mollusca } \\
\hline \multicolumn{8}{|l|}{ Gastropoda } \\
\hline \multirow[t]{2}{*}{ Pulmonata } & Enidae & 422 & 267 & 428 & 2 & 2 & 2 \\
\hline & Hygromiidae & 8 & 16 & - & 1 & 1 & - \\
\hline
\end{tabular}


Table 2. Fitting environmental factors, temporal and spatial variables, and technosol type onto a CA ordination.

\begin{tabular}{|c|c|c|c|c|c|c|c|}
\hline \multirow{2}{*}{ Predictors } & \multicolumn{4}{|c|}{ Axes, \% inertia explained } & \multirow{2}{*}{$R^{2}$} & \multirow{2}{*}{$\operatorname{Pr}(>\mathbf{r})$} & \multirow{2}{*}{ Significance codes } \\
\hline & CA1, 8.6 & CA2, 4.1 & CA3, 3.5 & CA4, 3.0 & & & \\
\hline \multicolumn{8}{|c|}{ Climatic predictors } \\
\hline Precipitation & -0.63 & 0.74 & 0.03 & 0.23 & 0.09 & 0.001 & $* * *$ \\
\hline Wind & -0.25 & -0.55 & -0.08 & -0.79 & 0.07 & 0.001 & $* * *$ \\
\hline $\mathrm{T}_{\min }$ & 0.40 & 0.89 & 0.04 & 0.18 & 0.33 & 0.001 & $* * *$ \\
\hline $\mathrm{T}_{\max }$ & 0.30 & 0.86 & 0.08 & 0.40 & 0.29 & 0.001 & $* * *$ \\
\hline $\mathrm{T}$ & 0.38 & 0.88 & 0.06 & 0.28 & 0.33 & 0.001 & $* * *$ \\
\hline Hum & -0.77 & -0.26 & -0.14 & -0.57 & 0.08 & 0.001 & $* * *$ \\
\hline Pres & 0.66 & -0.16 & -0.16 & -0.71 & 0.18 & 0.001 & $* * *$ \\
\hline RAW & -0.96 & 0.09 & 0.01 & 0.27 & 0.93 & 0.001 & $* * *$ \\
\hline \multicolumn{8}{|c|}{ Time predictors } \\
\hline Time_1 & 0.94 & -0.20 & 0.06 & 0.26 & 0.56 & 0.001 & $* * *$ \\
\hline Time_2 & -0.13 & -0.91 & -0.02 & -0.39 & 0.29 & 0.001 & $* * *$ \\
\hline Time_3 & 0.90 & 0.35 & 0.05 & 0.26 & 0.15 & 0.001 & $* * *$ \\
\hline Time_4 & -0.44 & -0.84 & -0.13 & -0.28 & 0.08 & 0.001 & $* * *$ \\
\hline Time_5 & -0.97 & 0.16 & 0.12 & -0.16 & 0.07 & 0.001 & $* * *$ \\
\hline Time_6 & -0.25 & -0.93 & -0.10 & -0.25 & 0.04 & 0.001 & $* * *$ \\
\hline Time_7 & 0.95 & 0.23 & -0.09 & 0.17 & 0.02 & 0.001 & $* * *$ \\
\hline \multicolumn{8}{|c|}{ Spatial predictors } \\
\hline Spat_1 & -0.06 & 0.16 & 0.91 & -0.39 & 0.38 & 0.001 & $* * *$ \\
\hline Spat_2 & 0.02 & 0.04 & -0.97 & -0.24 & 0.45 & 0.001 & $* * *$ \\
\hline Spat_3 & 0.06 & 0.22 & 0.56 & -0.80 & 0.09 & 0.001 & $* * *$ \\
\hline Spat_4 & 0.14 & 0.51 & 0.37 & 0.76 & 0.03 & 0.001 & $* * *$ \\
\hline Spat_5 & -0.06 & -0.72 & 0.32 & -0.61 & 0.01 & 0.007 & $* *$ \\
\hline Spat_6 & -0.43 & 0.09 & -0.40 & -0.81 & 0.01 & 0.044 & $\star$ \\
\hline Spat_7 & 0.90 & 0.11 & 0.01 & 0.42 & 0.00 & 0.997 & \\
\hline Spat_8 & 0.00 & 0.84 & 0.53 & 0.15 & 0.00 & 0.678 & \\
\hline Spat_9 & 0.21 & -0.42 & 0.44 & 0.77 & 0.00 & 0.474 & \\
\hline \multicolumn{8}{|c|}{ Technosol types } \\
\hline Technosols & - & - & - & - & 0.21 & 0.001 & $* * *$ \\
\hline GG & 0.03 & -0.11 & 0.90 & 0.22 & - & - & - \\
\hline $\mathrm{LL}$ & -0.07 & 0.12 & 0.75 & -0.47 & - & - & - \\
\hline $\mathrm{PZ}$ & -0.03 & -0.26 & -0.81 & 0.39 & - & - & - \\
\hline $\mathrm{RB}$ & 0.03 & 0.10 & 0.43 & 0.29 & - & - & - \\
\hline TM & 0.07 & 0.03 & -1.25 & -0.27 & - & - & - \\
\hline
\end{tabular}

Notes: Significance codes: ${ }^{* *},<0.001 ;{ }^{\star *},<0.01 ;^{\star},<0.05$.

The soil moisture influence with taking into account of the conditional effect of the time, space, technosol type, and meteorological factors can explain $2.1 \%$ of the community variation $(F=44.04, p<0.001)$. CCA axis statistically significantly correlates with readily available water $(r=-0.53, p<0.001)$. The statistically significant correlation of this axis with meteorological parameters, time, and space variables was not found. There is no statistically significant effect of the technosol type on this axis $(F=0.04, p=0.99)$. The species scores on CCA axis allow us to estimate the species optimum within the humidity gradient, and mean-square deviations of the species scores are indicators of tolerance to moisture conditions.

$K$-mean cluster analysis of the animal species on the basis of the optimum and tolerance estimations according to CCA ap- proaches allowed us to establish the presence of four clearly isolated clusters (Fig. 4). The optimal values and tolerance to the soil humidity are statistically significant different for the clusters ( $F$ $=444.6, p<0.001$ and $F=20.7, p<0.001$, respectively). Clusters can be meaningfully interpreted as ecological groups of animals which are characterized by specific relation to the soil moisture conditions. The most major ecological groups on the basis of the relationship to moisture conditions usually are designated as hygrophilous, mesophilous, and xerophilous. Phytoindication evaluation of humidity conditions on the studied technosols indicates a range from mesophilous to xerophilous. Therefore, the species group that is the most demanding of moisture conditions we identified as mesophilous. Accordingly, the species group that is able to survive under water-deficit conditions was identified as 


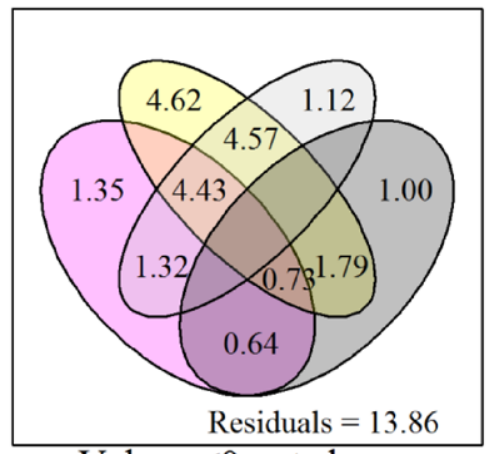

Values $<0$ not shown

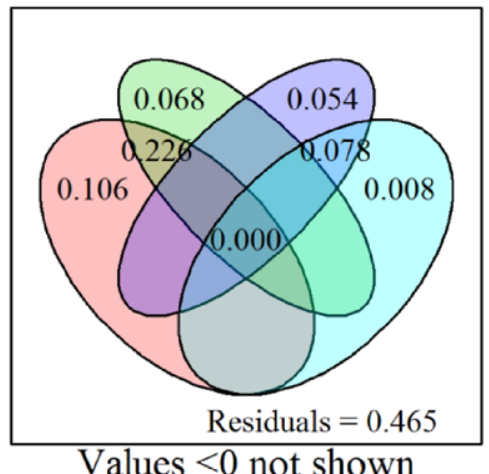

B

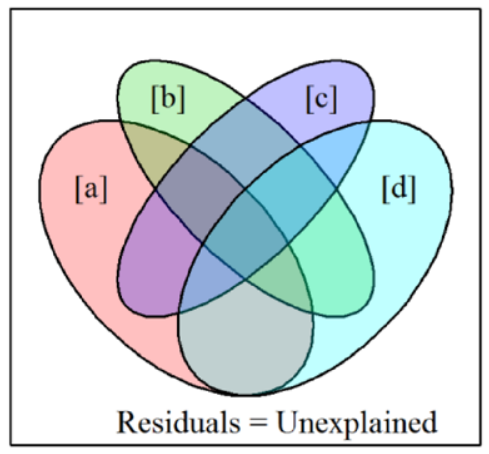

$\mathrm{C}$

Fig. 3. Variance partitioning between time, spatial, meteorological, and technosol type explanatory variables. A - using chi square in constrained correspondence analysis (CCA); B - using adjusted $R$-squared in redundancy analysis ordination (RDA); C - the meaning of the symbols.

Notes: [a] - variation explained solely by the meteorological variables; [b] - variation captured by temporal (dbMEM) variables corresponds to pure time; $[\mathrm{c}]$ - variation captured by spatial (dbMEM) variables corresponds to pure spatial; [d] - variation explained by technosol type; $[\mathrm{a}]+[\mathrm{b}]$ - variation explained both by meteorological and temporal variables; $[\mathrm{a}]+[\mathrm{c}]-$ variation explained both by meteorological and the spatial variables; $[\mathrm{b}]+[\mathrm{c}]$ - variation explained both by the spatial and temporal variables; $[\mathrm{c}]+[\mathrm{d}]$ - variation explained by spatial variables and technosol type. All the variance fractions shown are significant $(p<0.001)$.

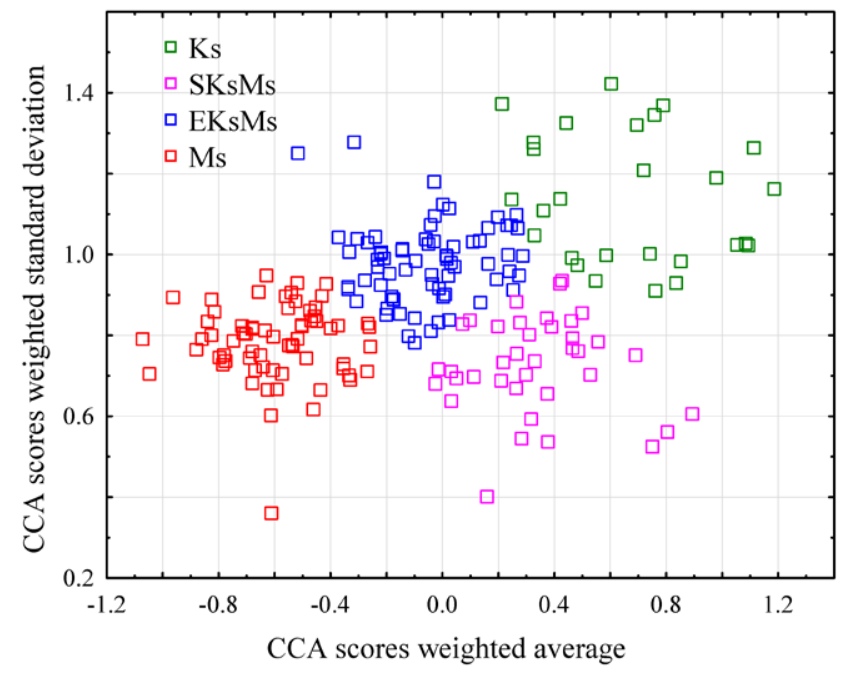

Fig. 4. $K$-means cluster analysis of the animal species on the basis of the optimum and tolerance estimations according to CCA approaches. Clusters: Ks - xerophilous (eurytopic), StKsMs - stenotopic xeromesophilous, EuKsMs - eurytopic xeromesophilous, Ms - mesophilous (stenotopic).

xerophilous. Species also show differences in tolerance to moisture conditions. Among the mesophilous species investigated are stenotopic, while xerophilous species are eurytopic. Within the humidity range between the xerophilous and the mesophilous species, there are two homogeneous ecological groups that are transitional in terms of preferences for humidity conditions and are different in tolerance. So we identified stenotopic and eurytopic xeromesophilous. The total number of mesophilous species is $66(32.7 \%$ of the total), xerophilous $-19(9.4 \%)$, stenotopic xeromesophilous - 48 (23.8\%), and eurytopic xeromesophilous $-69(34.2 \%)$. The optimum and tolerance estimations of ecological groups by CCA approach are significantly different from the assessments by other methods. The main difference is that the soil humidity optimum assessment without taking into account the effect of the other environmental factors, spatial and temporal variables, and technosol type for xerophilous and xerophilous is biased in the direction of the more humid conditions. The assessment for stenotopic xeromesophilous species is biased in the direction of more dry conditions. Assessing tolerance of the species is also somewhat displaced. So, by the method of weighted mean, xerophilous species are the most stenotopic and the level of the mesophilous tolerance is almost the same as eurytopic xeromesophilous.

\section{Discussion}

The communities of terrestrial invertebrates which were formed after a period of half a century of reclamation have high levels of species and taxonomic diversity. The communities formed in conditions of reclamation have been reported in some research to have high diversity, which even exceeds diversity in the natural equivalent of the transformed ecosystems (Sklenicka et al., 2004; Hendrychova et al., 2011; Ge et al., 2014; Hendrychova, 2008; Buchori et al., 2018). Niche-based and dispersal-based processes are considered as the principal factors responsible for community assembly (Cottenie, 2005). The partitioning of the community variation into environmental and spatial components is seen as an important approach to revealing various processes responsible for community structure (Dray et al., 2012). The environmental control on species distribution according to the niche theory will result in the variation of species composition explained by environmental variables (Chang et al., 2013). In our investigation, the spatial component of the community variation was modeled using dbMEM-spatial variables. These 
variables are able to reflect both the dispersion processes occurring in space and the effect of spatially structured environmental properties on animal communities. The time factor is also very important. Obviously, the impact of environmental factors is dependent on the biological state of the species, which is generally described by the term biological time. In other words, the same level of a factor's impact on the biological system, which is in various stages of development, will have a different effect. Therefore, the modeling of regular time processes is also important to correctly assess the species response to factor gradient. In our study, temporal component of the community variation was modeled using dbMEM-time variables.

The estimation of optimal level of an ecological factor for species living activity and its tolerance to such a factor could be made in many different ways (Izakovičová et al., 2020). A weighted mean can give unbiased assessment subject to symmetrical form of the species response. The symmetrical response close to the Gaussian bell-shaped curve may well be modeled using the regression approach. But in reality, the character of the species response to the impact of environmental factors is much more diverse, as the weighted mean method or regression approach gives adequate optimum assessment only for a limited number of cases. Estimations of species optima by different methods show a fairly high level of compliance. But it should be noted that the effects of other factors and interspecific interaction led to the shift of some species optima in the central part of the range of humidity: xerophilous or more mesophilic species manifest themselves as xeromesophilous. The shifting of xerophilous species is observed most intensively.

Among the models of the HOFJO list, the concept of a single optimum is presented only by models IV and V. For other models, optimum evaluation can be made to a great extent only on the assumption of convenience. Thus, the model II that provides optimum, if it exists, is outside the studied range of environmental factors, and factors' marginal value (the smallest or largest) as the optimum is selected as the best estimate from the existing ones. Model III simulates the presence not of an optimum point but the optimal range of the uniformly optimal values. As a compromise, the optimum evaluation is calculated as the average value of the optimal range. Bimodal distributions are simulated by the models VI and VII. The averaging of the two optima implies that that the bimodal model is the result of the transformation of the initially unimodal response under the influence of other factors and that the real optimum is between the two optima in a bimodal distribution.

The observed optimum is the result of a factor and the other factors and the interspecific interactions in the community (Tarjuelo et al., 2017). The impact on species of other factors that are not correlated with the focal factor leads to an increase in variation of the species response, i.e., increasing tolerance. The synergy or antagonism in the effects of other factors will cause a shift of the estimated optimum value. Also important is the consideration of the interspecific interactions in a community which influence the observed pattern of the species response to the factors studied. This task can be performed using ordination techniques such as RDA or CCA with variable humidity as predictors and other factors as covariates. The RDA ordination technique requires a monotone impact of environmental factors on species, and CCA requires unimodal response. Unlike RDA or CCA, non-metric multidimensional scaling (NMDS) is not sensitive to species response models and in this sense has the advantage over these two methods. Non-metric multidimensional scaling was recommended as a robust technique for indirect gradient analysis (Minchin, 1987). But constrained NMDS is not very well developed (ter Braak, Smilauer, 2015), which is why we used alternative methods - RDA or CCA. As shown by the results obtained, most often the unimodal model is most suitable to explain patterns of species response to the impact of soil moisture because the CCA approach is most suitable.

The stress-gradient hypothesis suggests that under high abiotic stress species, interactions will tend to be more facilitative, and under low abiotic stress, they will tend to be more competitive (Bertness, Callaway, 1994; Bowker et al., 2010). This hypothesis needs further verification, but the results we received indicate the different patterns of a species response to humidity gradient. In more dry conditions, the prevalent distributions are unimodal asymmetric, and in more moist - bimodal, and in moderate conditions, the distributions are symmetric unimodal. The bimodal models were suggested for species responses which are under the significant influence of biotic factors (Jansen, Oksanen, 2013). Thus, the data we obtained do not contradict the stress-gradient hypothesis. The underlying cause of asymmetry in a species response to an environmental gradient could be explained by the varying strength of abiotic and biotic factors on cold and warm limits of the gradient, respectively (Dvorský et al., 2017). The asymmetrical nature of the responses of species in conditions of deficiency of moisture can be explained by the more physiologically stressful influence of abiotic factors, when a comparatively small decrease in humidity can have a disproportionately large impact, resulting in asymmetry. In addition, one cannot exclude a purely mathematical nature of asymmetry in marginal positions when the asymmetry can be an artifact. The humidity range has a limited extent between the largest and lowest level, whereas Gaussian normal distribution has an infinite extent. However, asymmetric response mainly occurs exactly in the area of arid margin of the humidity range.

Critical niche dimensions vary between trophic or functional groups (Purse et al., 2012). Our results reveal that trophic groups differ in patterns of response to the influence of humidity. The differences may be due to the fact that saprophagous or litter-transforming (Lavelle et al., 1997) macro-arthropods tend to show lower levels of host or dietary specialization than other functional groups (Maraun et al., 2003). The specialization on particular microhabitats or land cover types may represent more critical niche dimensions than diet breadth for saprophagous macro-arthropods (Paoletti et al., 2007; David, Handa, 2010). Actually similar response patterns were detected for saprophages and predators. The representatives of these trophic groups have mostly a symmetrical unimodal (model IV) or an increasing or decreasing trend where the maximum is below the upper bound (model III) response type. In plant low-stress condition, the arthropod predator abundance was detected as increasing (Trotter et al., 2008). Soil decomposers were found to be highly sensitive to the reduction of the precipitations and may be eliminated by summer drought (Morón-Ríos et al., 2010).

The herbivorous response is an asymmetric unimodal or an asymmetric bimodal. This result indicates a significant heterogeneity of the herbivorous complex, which reflects an understanding that herbivore responses to plant stress spans two extremes, which are designated as plant stress and plant vigor hypotheses 
(Trotter et al., 2008). According to the plant stress hypothesis, some herbivores respond positively to increased plant stress, which may be among other things due to drought (White, 1976). Probably, asymmetric unimodal response type of herbivores may be explained by the plant stress hypothesis. Indeed, in some plants as stress increases, available nitrogen increases, while plant defenses are often negatively correlated with stress (White, 1984). In turn, the plant vigor hypothesis (Price, 1991) may explain an asymmetric unimodal response type of the herbivores. The herbivores exhibit increased performance when feeding on rapidly growing plants, as vigorously growing plant tissues may have increased nutritional content (Inbar et al., 2001). Obviously, favorable trophic conditions for herbivores may lead to intensification of the competition, the consequences of which may be modeled by an asymmetric bimodal response type.

\section{Conclusion}

In conditions of semi-arid climate and in an ecosystem which formed as a result of the reclamation process, the moisture content in the technosols is the most important factor determining the temporal dynamics of the terrestrial invertebrate community. The ecological features of species niche such as optimum and tolerance to the effects of environmental factors explain the temporal dynamics of the community structure. The weighted mean as a way to estimate the species optimum gives only a general idea about the ecological preferences of the species in the case of the unimodal species response model. Similarly, such a situation obtains for other indicators that do not include the effects of a combination of factors and interspecific interactions. Taking into account a combination of factors and interspecific interactions can significantly adjust the optimum value evaluation for a number of species. The deviations of species response to influence of soil moisture from symmetric bell-shaped form in different parts of the soil humidity range are due to different factors. The abiotic factors are predominant to producing asymmetric responses toward the physiologically more stressful ends of the soil water gradients. The biotic factors have predominant importance on the range margin with sufficient moisture condition. Not taking into account the role of soil moisture interaction with other factors leads to a shift in species optimum estimates to the central part of the range of humidity.

\section{Acknowledgements}

The authors are grateful to the staff of the "Dniprovsko-Orilsky" Nature Reserve for their support and assistance with this research. We thank Paul Bradbeer for checking the English text and the two anonymous reviewers for helping us to improve earlier versions of this paper.

\section{References}

Angeler, D.G., Drakare, S. \& Johnson R.K. (2011). Revealing the organization of complex adaptive systems through multivariate time series modeling. Ecology and Society, 16(3), 5. https://www.jstor.org/stable/26268950.

Bertness, M. \& Callaway R.M. (1994). Positive interactions in communities. Trends Ecol. Evol., 9(5), 191-193. DOI: 10.1016/0169-5347(94)90088-4.

Borcard, D. \& Legendre P. (2002). All-scale spatial analysis of ecological data by means of principal coordinates of neighbour matrices. Ecol. Model., 153, 51-68. DOI: 10.1016/S0304-3800(01)00501-4
Bowker, M.A., Soliveres, S. \& Maestre F.T. (2010). Competition increases with abiotic stress and regulates the diversity of biological soil crusts. $J$. Ecol., 98(3), 551-560. DOI: 10.1111/j.1365-2745.2010.01647.x.

Brandle, M., Durka, W., Krug, H. \& Brandl R. (2003). The assembly of local communities: plants and birds in non-reclaimed mining sites. Ecography, 26, 652-660. DOI: 10.1034/j.1600-0587.2003.03513.x.

Brown, J.H. (1984). On the relationship between abundance and distribution of species. Am. Nat., 124, 255-279. DOI: 10.1086/284267.

Brown, J.H. (1999). Macroecology: progress and prospect. Oikos, 87, 3-14. DOI: $10.2307 / 3546991$.

Buchori, D., Rizali, A., Rahayu, G.A. \& Mansur I. (2018). Insect diversity in post-mining areas: Investigating their potential role as bioindicator of reclamation success. Biodiversitas, 19, 1696-1702. DOI: 10.13057/biodiv/d190515.

Chang, L.-W., Zelený, D., Li, C.-F., Chiu, S.-T. \& Hsieh C.-F. (2013). Better environmental data may reverse conclusions about niche-and dispersalbased processes in community assembly. Ecology, 94, 2145-2151. DOI: 10.1890/12-2053.1.

Chase, J.M., Leibold, M.A., Downing, A.L. \& Shurin J.B. (2000). The effects of productivity, herbivory, and plant species turnover in grassland food webs. Ecology, 81(9), 2485-2497. DOI: 10.1890/0012-9658(2000)081[2485:TEOPHA]2.0.CO;2.

Chase, J.M. \& Myers J.A. (2011). Disentangling the importance of ecological niches from stochastic processes across scales. Philos. Trans. R. Soc. Lond. B Biol. Sci., 366, 2351-2363. DOI: 10.1098/rstb.2011.0063.

Collins, S.L., Belnap, J., Grimm, N.B., Rudgers, J.A., Dahm, C.N., D’Odorico, P., Litvak, M., Natvig, D.O., Peters, D.C., Pockman, W.T., Sinsabaugh, R.L. \& Wolf B.O. (2014). A multiscale, hierarchical model of pulse dynamics in arid-land ecosystems. Annual Review of Ecology, Evolution, and Systematics, 45, 397-419. DOI: 10.1146/annurev-ecolsys-120213-091650.

Colwell, R.K. \& Futuyma D.J. (1971). Measurement of niche breadth and overlap. Ecology, 52, 567-576. DOI: 10.2307/1934144.

Cottenie, K. (2005). Integrating environmental and spatial processes in ecological community dynamics. Ecol. Lett., 8, 1175-1182. DOI: 10.1111/j.1461-0248.2005.00820.x

Curtis, J.T. \& McIntosh R.P. (1951). An Upland Forest Continuum in the Prairie-Forest Border Region of Wisconsin. Ecology, 32, 476-496. DOI: $10.2307 / 1931725$.

David, J.F. \& Handa I.T. (2010). The ecology of saprophagus macroarthropods (millipedes, woodlice) in the context of global change. Biol. Rev., 85(4), 881-895. DOI: 10.1111/j.1469-185X.2010.00138.x.

Desender, K., Ervinck, A. \& Tack G. (1999). Beetle diversity and historical ecology of woodlands in Flanders. Belg. J. Zool., 129(1), 139-155.

Devictor, V., Clavel, J., Julliard, R., Lavergne, S., Mouillot, D., Thuiller, W., Venail, P., Villéger, S., \& Mouquet N. (2010). Defining and measuring ecological specialization. J. Appl. Ecol., 47, 15-25. DOI: 10.1111/j.13652664.2009.01744.x.

Dray, S., Legendre, P. \& Peres-Neto P. (2006). Spatial modeling: a comprehensive framework for principal coordinate analysis of neighbours matrices (PCNM). Ecol. Model., 196, 483-493. DOI: 10.1016/j.ecolmodel.2006.02.015

Dray, S., Pélissier, R., Couteron, P., Fortin, M.-J., Legendre, P., Peres-Neto, P.R., Bellier, E., Bivand, R., Blanchet, F.G., De Cáceres, M., Dufour, A.-B., Heegaard, E., Jombart, T., Munoz, F., Oksanen, J., Thioulouse, J. \& Wagner H.H. (2012). Community ecology in the age of multivariate multiscale spatial analysis. Ecol. Monogr., 82, 257-275. DOI: 10.1890/11-1183.1.

Dvorský, M., Macek, M., Kopecký, M., Wild, J. \& Doležal J. (2017). Niche asymmetry of vascular plants increases with elevation. J. Biogeogr., 44(6), 1418-1425. DOI: 10.1111/jbi.13001.

Entling, W., Schmidt, M.H., Bacher, S., Brandl, R. \& Nentwig W. (2007) Niche properties of Central European spiders: shading, moisture and the evolution of the habitat niche. Glob. Ecol. Biogeogr., 16, 440-448. DOI 10.1111/j.1466-8238.2006.00305.x.

Gaston, K.J., Blackburn, T.M. \& Lawton J.H. (1997). Interspecific abundancerange size relationships: an appraisal of mechanisms. J. Anim. Ecol., 66(44), 579-601. DOI: 10.2307/5951.

Gauch, H.G. \& Whittaker R.H. (1972). Coenocline simulation. Ecology, 53(3), 446-451. DOI: 10.2307/1934231.

Ge, B., Daizhen, Z., Jun, C., Huabin, Z., Chunlin, Z. \& Boping T. (2014). Biodiversity variations of soil macrofauna communitiesin forestsina reclaimed coastwith different diked history. Pak. J. Zool., 46(4), 1053-1059. 
Gregory, R.D. \& Gaston K.J. (2000). Explanations of commonness and rarity in British breeding birds: separating resource use and resource availability. Oikos, 88, 515-526. DOI: $10.1034 / j .1600$ 0706.2000.880307.x.

Hendrychova, M. (2008). Reclamation success in post-mining landscapes in the Czech Republic: a review of pedological and biological studies. Journal of Landscape Studies, 1, 63-78.

Hendrychova, M., Salek, M., Tajovsky, K. \& Reho M. (2011). Soil properties and species richness of invertebrates on afforested sites after brown coal mining. Restor. Ecol., 20 (5), 561-567. DOI: 10.1111/j.1526100X.2011.00841.x.

Hildmann, E. \& Wunsche M. (1996). Lignite mining and its after-effects on the central German landscape. Water Air Soil Pollut., (91), 79-87. DOI 10.1007/BF00280924

Hill, M.O. (1973). Reciprocal averaging: an eigenvector method of ordination. J. Ecol., 61(1), 237-249. DOI: 10.2307/2258931.

Hodecek, J., Kuras, T., Sipos, J. \& Dolny A. (2015). Post-industrial areas as successional habitats: long-term changes of functional diversity in beetle communities. Basic and Applied Ecology, 16(7), 629-640. DOI: 10.1016/j. baae.2015.06.004.

Hodecek, J., Kuras, T., Sipos, J. \& Dolny A. (2016). Role of reclamation in the formation of functional structure of beetle communities: A different approach to restoration. Ecological Engineering, 94, 537-544. DOI 10.1016/j.ecoleng.2016.06.027.

Huisman, J., Olff, H. \& Fresco L.F.M. (1993). A hierarchical set of models for species response analysis. J. Veg. Sci., 4(1), 37-46. DOI: 10.2307/3235732.

Hutchinson, G.E. (1957). Concluding remarks. Cold Spring Harbour Symp. Quant. Biol., 22, 415-427. DOI: 10.1101/SQB.1957.022.01.039.

Inbar, M., Doostdar, H. \& Mayer R.T. (2001). Suitability of stressed and vigorous plants to various insect herbivores. Oikos, 94(2), 228-235. DOI 10.1034/j.1600-0706.2001.940203.x.

Izakovičová, Z., Miklós, L., Miklósová, V. \& Raniak A. (2020). Integrated approach to the management of the landscape for the implementation of the Danube Strategy. Ekológia (Bratislava), 39(4), 357-379. DOI 10.2478/eko-2020-0029.

Jamil, T. \& ter Braak C.J.F. (2013). Generalized linear mixed models can detect unimodal species-environment relationships. PeerJ, 1:e95. DOI 10.7717/peerj.95.

Jansen, F. \& Oksanen J. (2013). How to model species responses along ecological gradients - Huisman-Olff-Fresco models revisited. J. Veg. Sci., 24, 1108-1117. DOI: $10.1111 /$ jvs.12050.

Klimkina, I., Kharytonov, M. \& Zhukov O. (2018). Trend analysis of watersoluble salts vertical migration in technogenic edaphotops of reclaimed mine dumps in Western Donbass (Ukraine). Journal of Environmental Research, Engineering and Management, 74(2), 82-93. DOI: 10.5755/j01. erem.74.2.19940.

Knapp, M., Seidl, M., Knappová, J., Macek, M. \& Saska P. (2019). Temporal changes in the spatial distribution of carabid beetles around arable field-woodlot boundaries. Scientific Reports, 9(1), 8967. DOI: 10.1038/ s41598-019-45378-7.

Kohn, A.J. (1968). Microhabitats, abundance, and food of Conus in the Maldive and Chagos Islands. Ecology, 49, 1046-1061. DOI $10.2307 / 1934489$

Kunah, O.M., Zelenko, Y.V., Fedushko, M.P., Babchenko, A.V., Sirovatko, V.O. \& Zhukov O.V. (2019). The temporal dynamics of readily available soil moisture for plants in the technosols of the Nikopol Manganese Ore Basin. Biosystems Diversity, 27(2), 156-162. DOI: 10.15421/011921.

Kunakh, O.N., Kramarenko, S.S., Zhukov, A.V., Zadorozhnaya, G.A. \& Kramarenko A.S. (2018). Intra-population spatial structure of the land snail Vallonia pulchella (Müller, 1774) (Gastropoda; Pulmonata; Valloniidae). Ruthenica, 28 (3), 91-99.

Lavelle, P., Bignell, D., Lepage, M., Wolters, V., Roger, P., Ineson, P., Heal, O.W. \& Dhillion S. (1997). Soil function in a changing world: the role of invertebrate ecosystem engineers. European Journal of Soil Science, 33 159-193.

Lawton, J.H. (1999). Are there general laws in ecology? Oikos, 84, 177-192. DOI: $10.2307 / 3546712$.

Legendre, P. \& Birks H.J.B. (2012). From classical to canonical ordination. In H.J.B. Birks, A.F. Lotter, S. Juggins \& J.P. Smol (Eds.), Tracking environmental change using lake sediments: Data handling and numerical techniques (pp. 201-248). Dordrecht: Springer.
Madej, G. \& Kozub M. (2014). Possibilities of using soil microarthropods, with emphasis on mites (Arachnida, Acari, Mesostigmata), in assessment of successional stages in a reclaimed coal mine dump (Pszów, S Poland). Biological Letters, 51(1), 19-36. DOI: 10.1515/biolet-2015-0003.

Maraun, M., Martens, H., Migge, S., Theenhaus, A. \& Scheu S. (2003). Adding to 'the enigma of soil animal diversity': fungal feeders and saprophagous soil invertebrates prefer similar food substrates. Eur. J. Soil Biol., 39, 85-95. DOI: 10.1016/S1164-5563(03)00006-2.

Michaelis, J. \& Diekmann M.R. (2017). Biased niches - Species response curves and niche attributes from Huisman-Olff-Fresco models change with differing species prevalence and frequency. PLOS ONE, 12(8), e0183152. DOI: 10.1371/journal.pone.0183152.

Minchin, P.R. (1987). An evaluation of the relative robustness of techniques for ecological ordination. Vegetatio, 69(1-3), 89-107. DOI: 10.1007/BF00038690.

Morón-Ríos, A., Rodríguez, M.Á., Pérez-Camacho, L. \& Rebollo S. (2010) Effects of seasonal grazing and precipitation regime on the soil macroinvertebrates of a Mediterranean old-field. Eur. J. Soil Biol., 46(2), 91-96. DOI: 10.1016/j.ejsobi.2009.12.008.

Okie, J.G., Van Horn, D.J., Storch, D., Barrett, J.E., Gooseff, M.N., Kopsova, L. \& Takacs-Vesbach C.D. (2015). Niche and metabolic principles explain patterns of diversity and distribution: theory and a case study with soil bacterial communities. Philos. Trans. R. Soc. Lond. B Biol. Sci., 282, 20142630. DOI: $10.1098 / \mathrm{rspb} .2014 .2630$.

Paoletti, M.G., Osler, G.H.R., Kinnear, A., Black, D.J., Thomson, L.J., Tsitsilas, A., Sharley, D., Judd, S., Neville, P. \& Dinca A. (2007). Detritivores as indicators of landscape stress and soil degradation. Austr. J. Exp. Agric., 47(4), 412-423. DOI: 10.1071/EA05297.

Pontegnie, M., du Bus de Warnaffe, G. \& Lebruna Ph. (2005). Impacts of silvicultural practices on the structure of hemi-edaphic macrofauna community. Pedobiologia, 49(3), 199-210. DOI: 10.1016/j.pedobi.2004.09.005.

Price, P.W. (1991). The plant vigor hypothesis and herbivore attack. Oikos, 62 (2), 244-251. DOI: $10.2307 / 3545270$

Purse, B.V., Gregory, S.J., Harding, P. \& Roy H.E. (2012). Habitat use governs distribution patterns of saprophagous (litter-transforming) macroarthropods - a case study of British woodlice (Isopoda: Oniscidea). Eur. J. Entomol., 109, 543-552. DOI: 10.14411/eje.2012.068.

R Core Team (2019). A language and environment for statistical computing. In R: A language and environment for statistical computing. $\mathrm{R}$ Foundation for statistical computing, Vienna, Austria. https://www.R-project.org

Rehor, M., Lang, T. \& Eis M. (2006). Application of new methods in solving current reclamation issues of Severoceske doly, a.s. localities. World of Surface Mining, 6, 383-386.

Reynolds, J.F., Smith, D.M.S., Lambin, E.F., Turner, B.L., Mortimore, M., Batterbury, S.P., Downing, T.E., Dowlatabadi, H., Fernández, R.J., Herrick, J.E., Huber-Sannwald, E., Jiang, H., Leemans, R., Lynam, T., Maestre, F.T., Ayarza, M. \& Walker B. (2007). Global desertification: building a science for dryland development. Science, 316(5826), 847-51. DOI: 10.1126/science.1131634.

Schoener, T.W. (1974). The compression hypothesis and temporal resource partitioning. Proc. Nat. Acad. Sci., 71(10), 4169-4172. DOI: 10.1073/ pnas.71.10.4169.

Schwinning, S. \& Sala O.E. (2004). Hierarchy of responses to resource pulses in arid and semi-arid ecosystems. Oecologia, 141(2), 211-220. DOI: 10.1007/s00442-004-1520-8.

Sklenicka, P., Prikryl, I., Svoboda, I. \& Lhota T. (2004). Non-productive principles of landscape rehabilitation after long-term opencast mining in north-west Bohemia. Journal of the South African Institute of Mining and Metallurgy, 104, 83-88.

Šmilauer, P. \& Lepš J. (2014). Multivariate Analysis of Ecological Data using CANOCO 5. Cambridge: Cambridge University Press. DOI: 10.1017/ CBO9781139627061.

Tarjuelo, R., Morales, M. B., Arroyo, B., Mañosa, S., Bota, G., Casas, F. \& Traba J. (2017). Intraspecific and interspecific competition induces densitydependent habitat niche shifts in an endangered steppe bird. Ecology and Evolution, 7(22), 9720-9730. DOI: 10.1002/ece3.3444.

ter Braak C.J.F. (1985). Correspondence analysis of incidence and abundance data: Properties in terms of a unimodal response model. Biometrics, 41(4), 859-873. DOI: $10.2307 / 2530959$.

ter Braak, C.J.F. \& Looman C.W.N. (1986). Weighted averaging, logistic regression and the Gaussian response model. Vegetatio, 65, 3-11. DOI: 10.1007/BF00032121. 
ter Braak C.J.F. \& Prentice I.C. (1988). A theory of gradient analysis. $A d v$. Ecol. Res., 18, 271-317. DOI: 10.1016/S0065-2504(08)60183-X.

ter Braak, C.J.F. \& Smilauer P. (2015). Topics in constrained and unconstrained ordination. Plant Ecol., 216(5), 683-696. DOI: 10.1007/s11258014-0356-5.

Tokeshi, M. (1999). Species coexistence: ecological and evolutionary perspectives. London: Blackwell Science.

Trotter, R.T., Cobb, N.S. \& Whitham T.G. (2008). Arthropod community diversity and trophic structure: a comparison between extremes of plant stress. Ecol. Entom., 33, 1-11. DOI: 10.1111/j.1365-2311.2007.00941.x.

White, T.C.R. (1976). Weather, food, and plagues of locusts. Oecologia, 22(2), 119 - 134. DOI: $10.1007 / \mathrm{BF} 00344712$.

White, T.C.R. (1984). The abundance of invertebrate herbivores in relation to the availability of nitrogen in stressed food plants. Oecologia, 63(1), 90-105. DOI: 10.1007/BF00379790.

Yorkina, N., Maslikova, K., Kunah, O. \& Zhukov O. (2018). Analysis of the spatial organization of Vallonia pulchella (Muller, 1774) ecological niche in Technosols (Nikopol manganese ore basin, Ukraine). Ecologica Montenegrina, 17, 29-45. www.biotaxa.org/em

Yorkina, N., Zhukov, O. \& Chromysheva O. (2019). Potential possibilities of soil mesofauna usage for biodiagnostics of soil contamination by heavy metals. Ekológia (Bratislava), 38(1), 1-10. DOI: 10.2478/eko-2019-0001.
Zadorozhnaya, G.A., Andrusevych, K.V. \& Zhukov O.V. (2018). Soil heterogeneity after recultivation: ecological aspect. Folia Oecologica, 45 (1) 46-52. DOI: 10.2478/foecol-2018-0005.

Zhenqi, H., Peijun, W. \& Jing L. (2012). Ecological restoration of abandoned Mine land in China. Journal of Resources and Ecology, 3(4), 289-296. DOI: 10.5814/j.issn.1674-764x.2012.04.001.

Zhukov, A. \& Gadorozhnaya G. (2016). Spatial heterogeneity of mechanical impedance of a typical chernozem: the ecological approach. Ekológia (Bratislava), 35, 263-278. DOI: 10.1515/eko-2016-0021.

Zhukov, O., Kunah, O., Dubinina, Y. \& Novikova V. (2018). The role of edaphic and vegetation factors in structuring beta diversity of the soil macrofauna community of the Dnipro river arena terrace. Ekológia (Bratislava), 37(3), 301-327. DOI: 10.2478/eko-2018-0023.

Zhukov, O.V. \& Maslikova K.P. (2018). The dependence of the technosols models functional properties from the primary stratigraphy designs. Journal of Geology, Geography and Geoecology, 27(2), 399-407. DOI: $10.15421 / 111864$ 